\title{
Biosystematics Studies on the Greens Used By Local Inhabitants of Pothamalai Hills In, Namakkal District, Tamil Nadu, India
}

\author{
G. Sathiyaraj ${ }^{\star}$, R. Kumuthakalavalli \\ Department of Botany, Gandhigram Rural University, Gandhigram, Dindugal - 624 302, \\ Tamil Nadu, India \\ *E-mail address: sathyagjg@gmail.com
}

\begin{abstract}
The present study mainly focuses on the ethno-botanical importance of greens, used by the Pothamalai, Puduppatti, Vadugam, Malaiyampatti, Seerappalli and Rasipuram local people in Namakkal districts. From this investigation 25 species of green belonging to19 genera and 13 families are recorded. This information regarding on correct botanical identity with family, vernacular name, systematic description and medicinal uses was observed. During the survey brought out some popular medicinal plants frequently used by the local villagers for minor ailments such as felt by the respondents were greens are good for health, increase the blood level, clear vision, to cure sore in the stomach and mouth, prevent the jaundice, cure the heart diseases, release the knees pain, and sugar disorder. The greens are good food for children and give essential nutrient for pregnant women.
\end{abstract}

Keywords: Ethno-medicine; Greens; Systematic description; Pothamalai; Local people

\section{INTRODUCTION}

Nature abounds in a variety of green leaves, the researches shows that this provides the ready answers to the ordinary ailments of life. Those greens were common, for our ancient ancestors to eat up to six pounds of leaves per day (Ughade et al, 1998). In remote rural settlements where vegetable cultivation is not practiced and market supplies are not organized, local inhabitants depend on indigenous vegetables, both cultivated in kitchen gardens and wild, for enriching the diversity of food (Bussmann and Sharon 2006, Kunwar et al. 2006, Cavender 2006, Pieroni et al. 2007). However, nutritionally vegetables have good sources of vitamins and minerals to the human diet (Arora and Neha 1987, Teotia et al, 1988, Ogunda 1998, Nalwade, Reddy and Kokil, 2001, Kawashima 2003, Leterme et al., 2006, Pandey 2008). Hence, India is endowed with an array of leafy vegetables suited for tropical, sub-tropical and temperate climates to be grown all the year round. Leafy vegetables are appreciated because they not only supply the protective nutrients and add variety to a monotonous diet, but also have an alternative taste, pleasing appearance and aroma (Praveen Sharma et al., 2010). Majority of the Indian population is vegetarian, and daily intake of at 
least $100 \mathrm{~g}$ of fresh green leafy vegetable is recommended by the nutrition experts (Reddy, 1999).

Green leafy vegetables are the cheapest of all the vegetables within the reach of poor man, being richest in their nutritional value and also the medicinal values of greens are good for health, increase the blood level, clear vision, to cure sore in the stomach and mouth, prevent the jaundice, cure the heart diseases, release the knees pain, sugar disorder and the greens are good food for children and give essential nutrient for pregnant women (Rao et al., 1980, Kuhnlein, 1996, Saxena, 1999). Based on the advantages of green leafy vegetables for healthcare, this study is attempted to document the greens used by villagers of Namakkal districts and studied with systematic for their nutrition for their medicinal value.

\section{MATERIALS AND METHODS}

The major survey area was conducted during 2010-2011, during these survey data on house hold composition based on the village census, the diversity of wild green available for use were documented. Informal discussion and village walks with key informants both adult and children were held to enhance understanding and gather information about different species of wild food greens available around the villages and in cultivated areas. In this survey five villages consisting fifty households with 125 individuals were interviewed to document the knowledge.
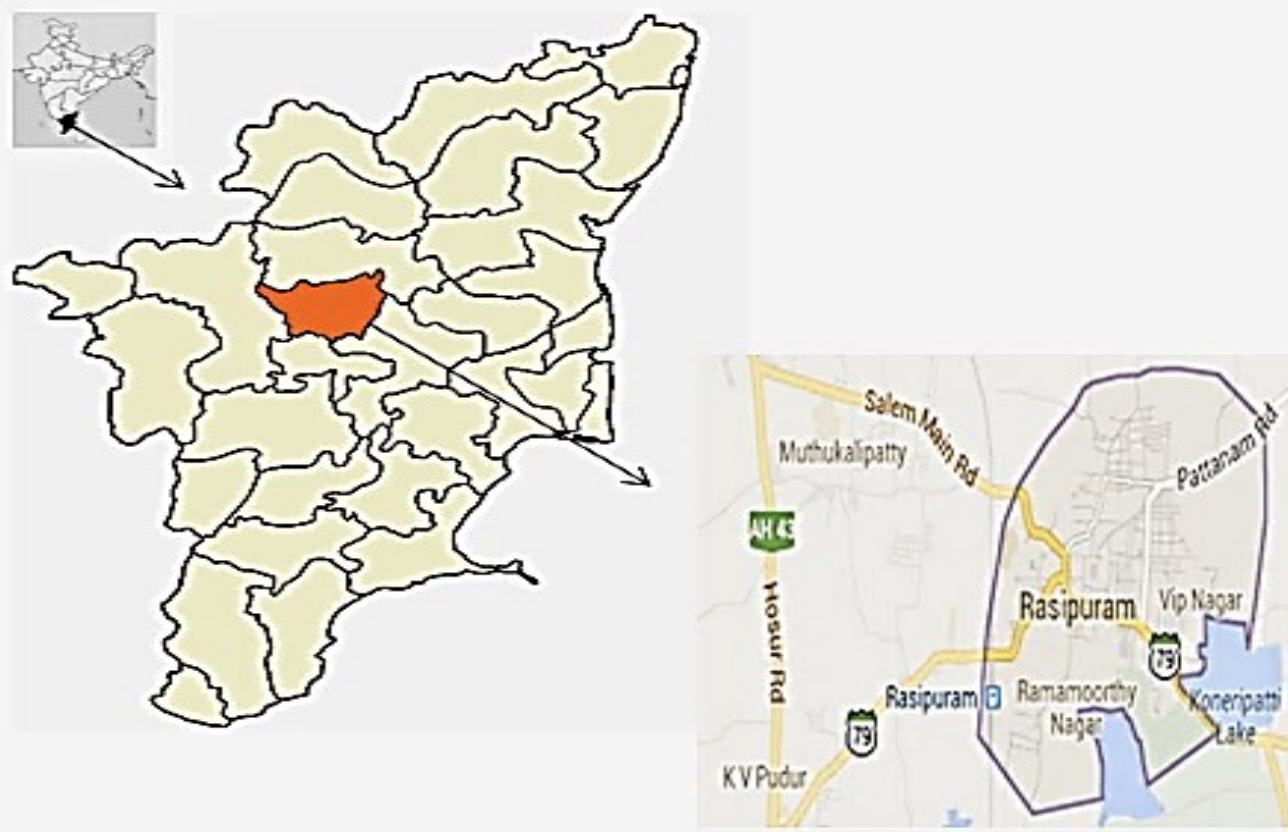

Poosaralayan tike

lap data 60014 Google

Figure 1. Study Area of the present study. 
For this study five villages of Rasipuram taluk were selected, namely pothamalai, Pudhuppatti, Malayampatti, Vadugam and Seerapalli (Fig. 1). These five villages were chosen for the study, for the reason that they are away from the Namakkal town and villagers depend on their own resources for food commodities such as vegetables greens.

\section{1. Data collection procedure}

The interview method was used for conducting the survey form, the interview schedule contain question on personal and family back ground of the respondent, varieties of green used, nutritional value and medicinal advantages use of greens.

\section{2. Selection of Respondents}

Respondents selected for this study were women. $60 \%$ of them age group of above 45 years and twenty five respondents from each village were selected. The survey consists of one hundred twenty five respondents. Prioritization of the leafy vegetables was done using a set of criteria such as Nutritional and medicinal uses.

\section{RESULTS AND DISCUSSION}

This survey observed nearly 25 species of greens from the area are enumerated with botanical name, family, local name, parts used and medicinal uses.

\section{1. Sirukeerai}

Botanical name: Amaranthus polygonoides

Family name : Amaranthaceae

Parts used : whole plant

Medicinal value: Leaves are slightly sweet in taste, Improves beauty, It is very effective in the treatments of Eye diseases, Cough, Ulcers, Difficulty in urination, and Swelling. Regular consumption of this green also benefits those with hemorrhoids, skin conditions like scabies and eczema.

The plant: A small herb; branchlets erect or ascending. Leaves oblong- lanceolate, obtuse or acute, entire or toothed. Flowers in axillary spikes. Fruit an utricle, enclosed in the perianth.

\section{2. Ponnanganni keerai}

Botanical name: Alternanthera sessilis

Family name : Amaranthaceae

Parts used : whole plant

Medicinal value: it neutralizes excessive acidity in the body, specifically

recommended in the case of Fever, Eye ailments. It is cooling; it gradually induces a change, and restores healthy functions without evacuations.

The plant: A much branched prostrate herb, rooting at the lower nodes. Leaves simple, opposite, lanceolate, oblanceolate, or linear oblong, obtuse or sub acute, shortly, petiolate. Flowers small in axillary spikes. utricles obcordate; seeds sub orbicular. 


\section{3. Thandukeerai}

Botanical name: Amaranthus gangeticus

Family name : Amaranthaceae

Parts used : whole plant

Medicinal value: It is very good blood cleanser, this green is also strengthens the heart, it loosens stools and helps treat painful and difficult urination due to increase in body heat.

The plant: An erect herb, 30-60 cm in high; branchlets grooved. Leaves simple, alternate, ovate, lanceolate or oblong, entire, glabrous above, main nerves numerous. Flowers small, sessile, in axillary spikes.

\section{4. Araikeerai}

Botanical name: Amaranthus dubius

Family name : Amaranthaceae

Parts used : Leaf

Medicinal value: It is a stimulant and an aphrodisiac, rejuvenator, strengthens the tissues of the body, cure Fevers, Cough, and Rheumatism.

The plant: An erect, divarcately branched, herb, 30-60 $\mathrm{cm}$ high. Leaves ovate or oblong, sinuate-toothed or lobed, glabrous. flowers in axillary pikes. Utricle ovoid.

\section{5. Mulaikeerai}

Botanical name: Amaranthus spinosus

Family name : Amaranthaceae

Parts used : whole plant

Medicinal value: it cools and energizes the body, Reduces vata and pitta, Good for children, Relieves cough and fever.

The plant: An erect, spinous herb, 60-100 cm high. Leaves ovate, lanceolate- oblong, entire. Flowers pale green, in dense axillary clusters and in terminal or interrupted spikes. Capsules ovoid.

\section{6. Kumitti keerai}

Botanical name: Allmania nodiflora

Family name : Amaranthaceae

Parts used : Leaf

Medicinal value: Leaves is used as a vegetable which is a rich source of iron.

The plant: Erect herbs. Leaves 2-3.5 x 1-2 cm, obovate, apex obtuse or acute, pubescent below.Flowers in axillary clusters, bracts $2 \mathrm{~mm}$, ovate; bracteoles 0.2-0.5 $\mathrm{cm}$, awned, ciliate; tepals 5, $0.4 \mathrm{~cm}$ long, lanceolate, ciliate on the back; filaments connate at the base, $0.2 \mathrm{~cm}$; ovary $0.2 \mathrm{~cm}$, style $0.1 \mathrm{~cm}$, stigma 2 fid.

\section{7. Pannakeerai}

Botanical name: Celosia argentea

Family name : Amaranthaceae

Parts used : Leaf

Medicinal value: Regular consumption of this greens helps ward off ulcerative colitis, stomatitis, sore throat and similar conditions. It also found to be useful in treating 
eczema, and venereal diseases,

The plant: Erect herb. Leaves elliptic - lanceolate, $4-12 \times 0.5-1.2 \mathrm{~cm}$, margin entire, acuminate at apex; petiole $1 \mathrm{~cm}$ long. Flowers white in terminal, cylindrical spikes. Capsule globose; seeds $>10$, reticulate.

\section{8. Thoyyakeerai}

Botanical name: Digera muricata

Family name : Amaranthaceae

Parts used : whole plant

Medicinal value: The plants are occasionally cultivated in agricultural land, it cure fever, cold and cough. Farmers are well knowingly aware about this merit.

The plant: Erect herb, 30-50 cm high. Leaves ovate - lanceolate, 4-6 x 1.5-2 cm, apex acute, base rounded, margin wavy. Flowers in cymules of spike. Fruits ovoid.

\section{9. Kuppakeerai}

Botanical name: Amaranthus viridis

Family name : Amaranthaceae

Parts used : Leaf

Medicinal value: it improves digestive power, balances vata and pitta, and mostly used for food sources.

The plant: Erect herbs, 30-60 cm high. Leaves alternate, ovate, 5-10 x 2-5 cm, acute, truncate at base; nerves 3-6 pairs. Spikes terminal and axillary, interrupted. Flowers unisexual, mixed, densely arranged; bracts and bracteoles similar, ovate, acuminate; tepals 3, $1.5 \mathrm{~mm}$ long, obovate, obtuse; stamens 3, free; ovary obovoid, styles 2, free. Achenes 2 x $1 \mathrm{~mm}$, ovoid, acute, membranous; seeds biconvex, dark brown, shining with hexagonal epidermal cells.

\section{10. Thuthuvalai}

Botanical name: Solanum trilobatum

Family name : Solanaceae

Parts used : whole plant

Medicinal value: This green is an excellent remedy for people suffering from sinus related conditions. It is also used to cure asthma, cold and fever.

The plant : Armed climber; branchlets prickly. Leaves ovate, margin wavy, base truncate-acute, acute at apex. Flowers blue in extra axillary cymes. Berries globose, seeds discoid.

\section{11. Manathakkalli}

Botanical name: Solanum nigrum

Family : Solanaceae

Parts used : whole plant

Medicinal value: it has been very effective in treating all types of internal ulcers, stomach and mouth ulcers. Leaves are being administered for good health vision, Reduce the heat and knee pain,

The plant : An erect herb, 30-50 cm high. Leaves ovate or oblong, sinuate-toothed or lobed, glabrous. Flowers white, 3-8 in extra-axillary drooping sub umbellate cymes. 
Berries globose, purplish black when ripe; seeds many, discoid, yellow, minutely pitted.

\section{Kothamalli keerai}

\section{Botanical name: Coriandrum sativum \\ Family name : Apiaceae}

Parts used : leaves, fruits.

Medicinal value: coriander leaves are found to be effective in alleviating digestive problems. It helps in lowering blood glucose levels in diabetics. It protects urinary tract infection during summer season. It helps curing anemia, and prevents nausea and vomiting.

The plant : Erect herb, 30-90 cm high; stem hollow. Leaves compound, lower ones long - petiolate and upper ones short petiolate or sub-sessile. Flowers small, white or pinkish purple in compound terminal umbels. Fruits yellowish brown, globular and ribbed, separating into two halves (mericarps) each containing a seed.

\section{13. Vallarai}

Botanical name: Centella asiatica

Family name : Apiaceae.

Parts used : whole plant

Medicinal value: leaf paste mixed with goat milk is administered for venereal disease. It stimulates the nerve and brain tissues, the leaf are main ingredient in making Kayakalpa. It relieves worm infestation; it promotes the ejection of phlegm from lungs and trachea.

The plant : Runners rooting at nodes. Leaves simple, reniform or cordate, margin serrulate-crenate; petioles sheathing at leaf bases. Flowers pink, in axillary umbel. Cremocarps laterally compressed.

\section{14. Kilanelli}

Botanical name: Phyllanthus amarus

Family name : Euphorpiaceae

Parts used : whole plant

Medicinal value: It is mainly used for jaundice. The fresh root is used for the treatment of viral hepatitis. The plant is also used as a diuretic in oedema. It is also used to increase appetite and to relieve inflammations.

The plant : Annual herb, 30-60 cm high. Leaves elliptic-oblong, obtuse, base rounded. Flowers greenish yellow, axillary; males in groups of 1-3, females solitary. Capsules trilocular; seeds trigonous, pale brown with longitudinal parallel ribs on the back.

\section{15. Kuppaimeni}

Botanical name: Acalypha indica

Family name : Euphorbiaceae

Parts used : whole plant

Medicinal value: Plant paste ground with salt is applied externally to scabies. Leaf juice is given in cough and cold. The plant also improves digestive power.

The plant : An erect herb, Leaves ovate, acute, cuneate at base, crenate-serrate, 
glabrous. Male and female flowers in axillary spikes; male flowers minute, followed by a tuft of sterile flowers, the females scattered 3-5 surrounded by a many-nerved bract. Capsules, small, concealed by the bract; seeds ovoid, smooth.

\section{16. Puthina}

Botanical name: Mentha arvensis

Family name : Lamiaceae

Parts used : Leaves

Medicinal value: It is a good appetizer, Found to be effective in the treatment of Digestive disorders , Liver disorders, Gall bladder disorders, Anorexia, Vomiting, Poor digestion, Bleeding diseases. It is also a well known breath freshener.

The plant : An erect, aromatic herb up to $60 \mathrm{~cm}$ high with suckers. Leaves simple, opposite, oblong- ovate or lanceolate, crenate-serrate, and cuneate at the base. Flowers lilac in axillary distant whorls. Fruits a nut let, ovoid.

\section{17. Thumbai}

Botanical name: Leucas aspera

Family name : Lamiaceae

Parts used : Whole plant

Medicinal value: The plant is useful in epilepsy, hysteria, dyspepsia, colic, intestinal worms, scaties, antitode for snake poison, mosquito bite and skin diseases.

The plant : Erect herb, branchlets hispid. Leaves linear - elliptic, 6-9 × 1.5-2 $\mathrm{cm}$,. elliptic, apex obtuse, base cuneate, distantly serrate. Flowers in verticillaster, Flowers white; bracts $8 \mathrm{~mm}$ long, linear, ciliate, acute; calyx mouth oblique, $0.5 \mathrm{~cm}$, 10-toothed, ciliate with bulbous based hairs at apex; corolla tube $8 \mathrm{~mm}$, upper lobe 4 $\mathrm{mm}$, lower $8 \mathrm{~mm}$; filaments $0.4-0.5 \mathrm{~cm}$, pubescent: ovary $1 \mathrm{~cm}$, style $0.8 \mathrm{~cm}$ long.

\section{18. Pasalaikeerai}

Botanical name: Basella alba

Family : Basellaceae

Parts used : stems leaves

Medicinal value: cures the sugar disorder and body heat. It is well known remedy for diseases related to the urinary system. Used in treatment of Dropsy, Gonorrhea, Urinary disorders.

The plant : Climber; branchlets fleshy. Leaves simple, alternate, broadly ovate, acute or acuminate at apex, fleshy. Flowers white or red in spikes, bracteoles longer than perianth. Berries globose, purplish black when ripe.

\section{19. Agathi keerai}

Botanical name: Sesbania grandiflora

Family name : Fabaceae

Parts used : Root bark, leaves, flowers

Medicinal value: Agathi leaves strengthen the nerves of eyes and increase blood level; the juice of leaves reduces headache and body pain.

The plant : Trees, 6-9 m high, Leaves compound; leaflets linear- oblong deciduous. Flowers white, axiliary cymes. Pod septate with swollen margins. Seeds 15-50. 


\section{20. Paruppukeerai}

Botanical name: Portulaca oleracea

Family : Portulacaceae

Parts used : stem, leaves, seeds.

Medicinal value: Reduces Pitta, Increases the secretion of breast milk, It strengthens the stomach, Smoothens and protects the mucus membranes

The plant : A succulent prostrate herbs. Leaves simple, fleshy, oblong-ovate, spathulate, linear with cuneate sessile base. Flowers bright yellow, in sessile, terminal or axillary clusters. Capsules ovoid; seeds numerous, black.

\section{21. Murungai keerai}

Botanical name: Moringa oleifera

Family : Moringaceae

Parts used : roots, bark, leaves, seeds.

Medicinal value: The leaves are being administered for good health vision, reduce stomach pain, and cure the mouth sore and gas troubles. Relieves Loss of appetite, internal body head, Giddiness, Eye diseases

The plant : Trees, 3-6 m high. Leaves usually tri pinnate; leaflets elliptic or obovate, rounded at the apex, nerves obscure. Flowers white in axillary panicles. Capsule 25- $45 \mathrm{~cm}$ long, pendulous, greenish, triangular; seeds trigonous, winged.

\section{22. Kariveppilai}

Botanical name: Murraya koenigii

Family name : Rutaceae

Parts used : Roots, bark, leaves.

Medicinal value: It is mainly rectifying the blood circulation; the leaves are also used as antieoriodic. It is used to treat Dysentery, Diarrhea, Insanity, Fever, Disorders of liver.

The plant: Trees, 3-5 m high. Leaves imparipinnate, alternate, leaflets obliquely ovate or rhomboid, gland dotted and strongly aromatic. Flowers white, in much branched terminal corymbose cymes. Berries subglobose or ellipsoid.

\section{23. Mustack keerai}

\section{Botanical name: Rivea hypocrateriformis}

Family name : Convolvulaceae

Parts used : leaf

Medicinal value: relieve body pain, cure fever and body heat.

The plant : Leaves cordiform, 3-4 x 3-6 cm, subcoriaceous, base cordate, apex obtuse'; petiole to $6 \mathrm{~cm}$. Flowers axillary, solitary or in cymes; bracts lanceolate; corolla white, $7 \mathrm{~cm}$ across, salver-form; stamens 5, unequal, to $1.8 \mathrm{~cm}$; anthers oblong, $4 \mathrm{~mm}$; ovary oblong, $4 \mathrm{~mm}$, 4-locular, each 1 - ovulate, style $3.5 \mathrm{~cm}$. Capsule conical, indehiscent, $1.5 \times 1 \mathrm{~cm}, 1$-celled; seeds 4 or a few. 


\title{
3. 24. Mudakkatran keerai
}

\author{
Botanical name: Cardiospermum halicababum \\ Family name : Sapindaceae \\ Parts used : Root, leaves, seeds. \\ Medicinal value: It is a diuretic and a laxative, Strengthens the stomach, It is \\ specifically used in the treatments of Gout, Rheumatoid arthritis, Skin diseases, \\ Cough, Nervous disorders, Piles, Chronic bronchitis, Muscle wasting. \\ The plant : Climbers. Leaves ternately bicompound, leaflets acuminate at the apex. \\ Flowers in axillary, tendriliferous peduncle; polygamous. Petals unequal with scales. \\ Ovary villous. capsule pyriform, winged at the angles; seeds black with a large white \\ heart-shaped aril.
}

\section{25. Pulichakeerai}

Botanical name: Hibiscus cannabinus

Family name : Malvaceae

Parts used : Leaves stem.

Medicinal value: Consuming this green helps constipation, stomach ulcers, and digestive disorders. It is mild laxative, Emollient, softening and soothing, Aphrodisiac, stimulates sexual desires, Used in treatment of Lungs diseases, Skin diseases, Liver diseases, Spleen diseases, Intestinal disorders, Paralysis, Swelling. The plant: Erect herb, $60-150 \mathrm{~cm}$ in high. Leaves 3-7 lobed, lobes oblonglanceolate, cordate or truncate at the base, margin crenate-serrate. Flowers large, yellow with purple centre. Capsules ovoid; seeds traingular.

\section{RESULT}

The present investigation is an attempt to study the varieties of greens used by the respondents, their medicinal value, and suggestions for population of greens. A total 25 species of greens under 19 genera and 13 families were recorded. Among the 13 families, Amaranthaceae exhibited the maximum diversity in the area which harbors 9 species of wild greens. Followed by Amaranthaceae, Solanaceae, Lamiaceae, Apiaceae \& Euphorbiaceae harbors two species each.

\section{DISCUSSION}

From this result clearly noticed that Pothamalai hills having rich sources of greens. The tribal community solely depends on the forest products for their own herbal health care system. Amaranthus polygonoides (Sirukeerai), Alternanthera sessilis (Agathikeerai), Amaranthus gangeticus (Thandu keerai), Solanum nigrum (Milaguthakkalli), Coriandrum sativum (Coriander leaves), Mentha arvensis (Puthina), Moringa oleifera (Drumstick leaves), Murraya koenigii (Curry leaves), Hibiscus cannabinus (Pulichakeerai) are mainly used for daily food sources, as well as medicine. Alternanthera sessilis (Ponnanganni keerai), Celosia argentea (Vallarai), Amaranthus viridis (Kuppakeerai), Solanum trilobatum (Thuthuvalai), 
Figure 2. Ethno medicine of greens used by Pothamalai hills.

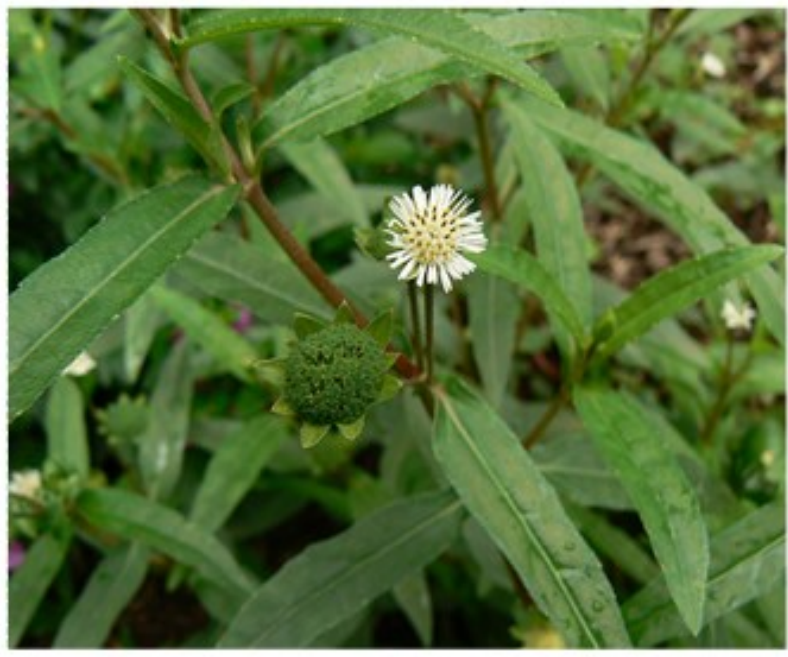

Alternowherm sositis

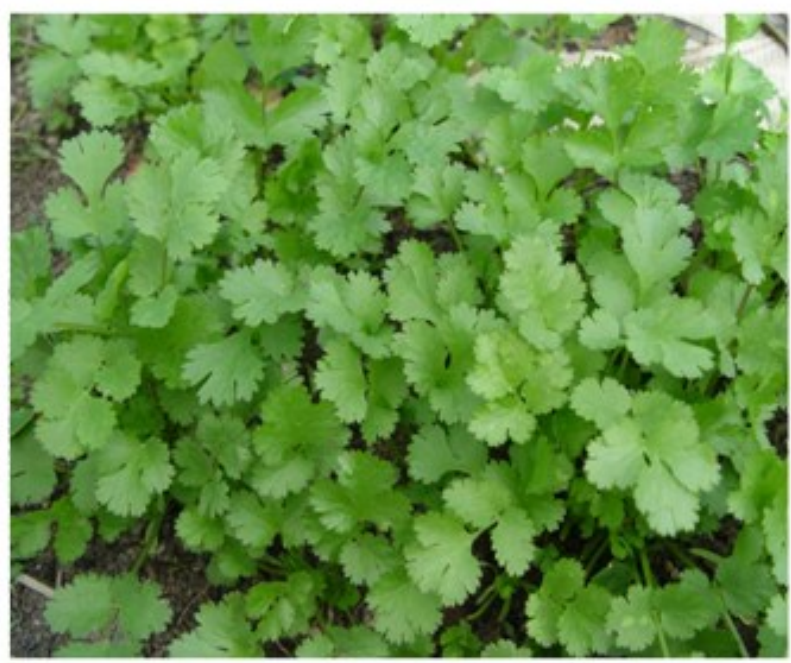

Coriandronsative.

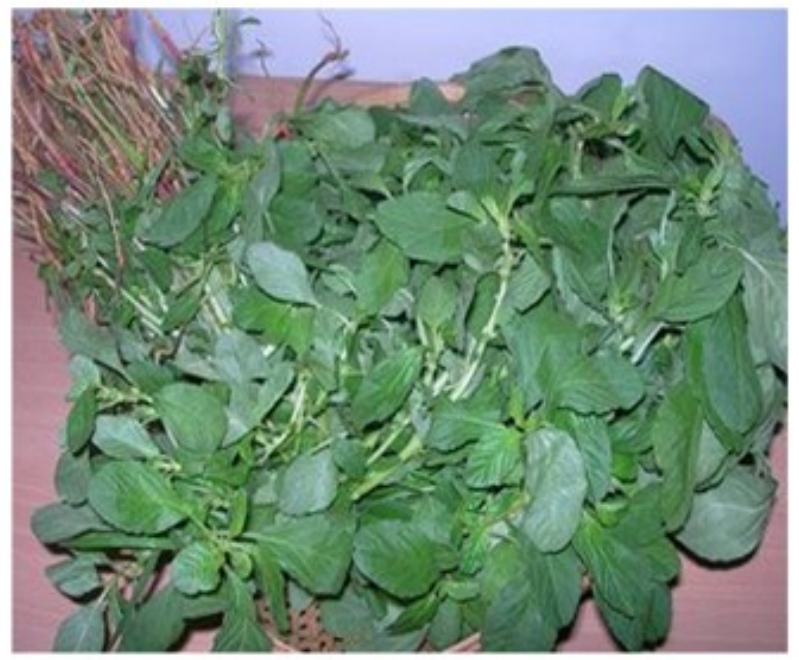

Amorediespolygonoids

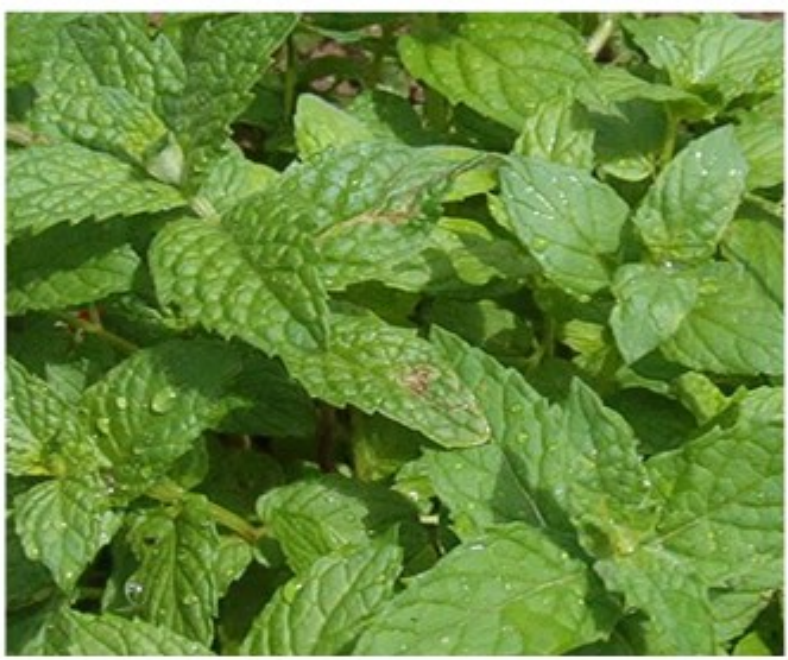

Nethe arvesis

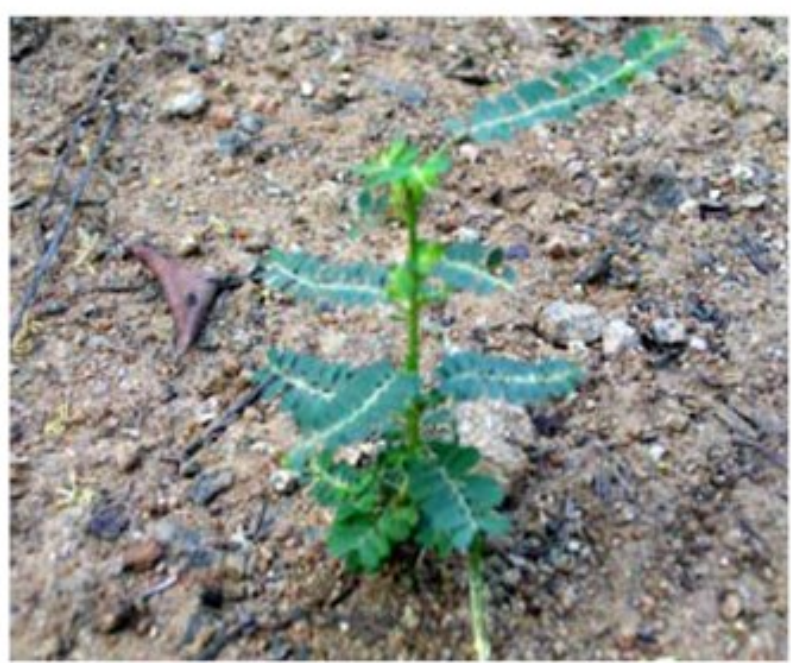

Fipllothes amares

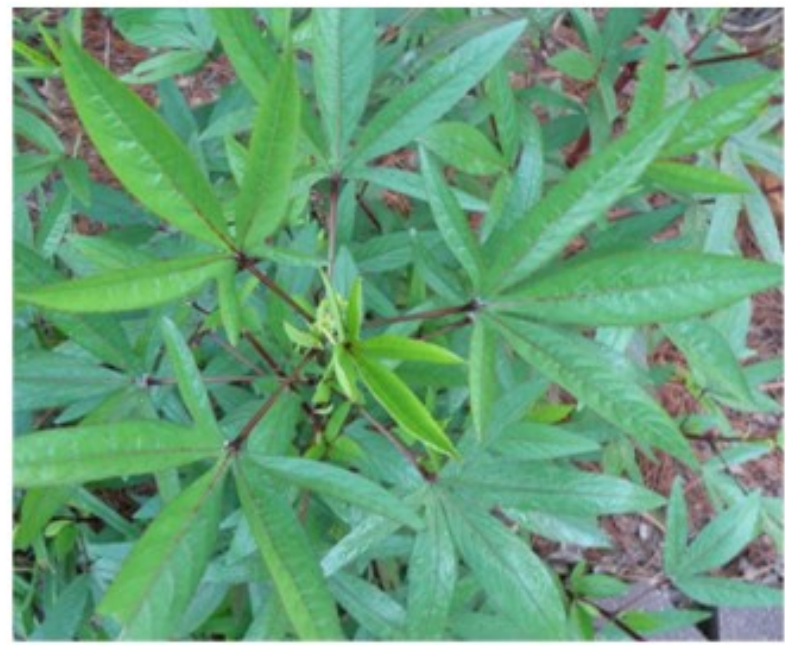

Hibisas comabines 
Amaranthus dubius (Araikeerai), Amaranthus spinosus (Mulaikeerai), Digera muricata (Thoyyakeerai), Phyllanthus amarus (Kilanelli), Allmania nodiflora (Kumitti keerai), Acalypha indica (Kuppaimeni), Leucas aspera (Thumbai), Basella alba (Pasalaikeerai), Portulaca oleracea (Paruppukeerai), Rivea hypocrateriformis (Mustack keerai), Cardiospermum halicababum (Mudakkatran keerai) leaves are used for traditional medicine in this study area (Fig. 2).

In regard Personal background of the respondents reveals that $42.4 \%$ of them are in the age range of 55-65 years. The educational status of the respondents reveals that $40.8 \%$ of them are illiterate and $52.8 \%$ of them are daily wages, $52 \%$ of them are income of below Rs. 18000 per annum, the $41.6 \%$ of them reported procuring greens from their working places (Fig. 3, 4).

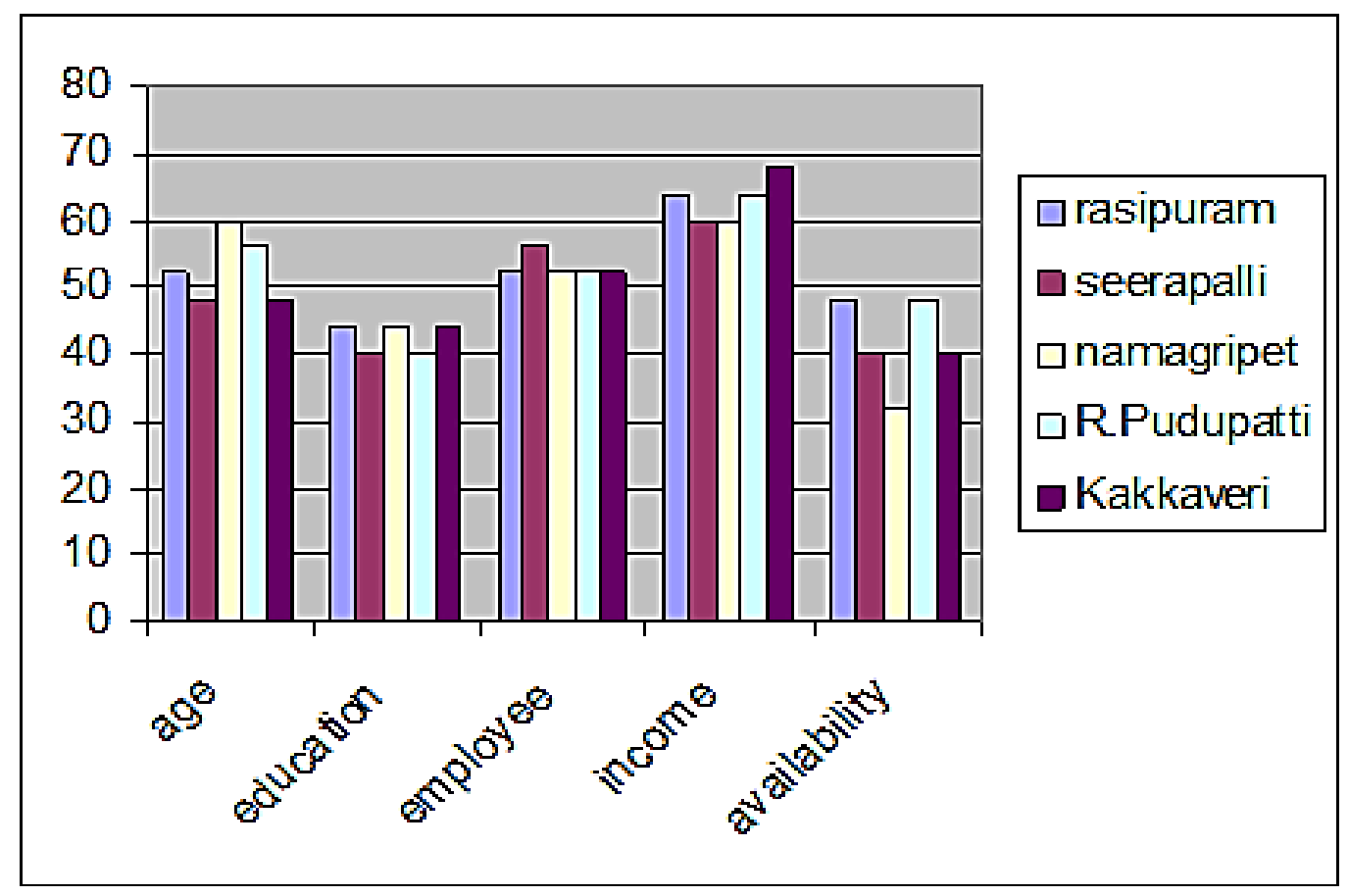

Figure 3. Status of the respondent of this study area.

It is evident from the observation that the local inhabitants of Pothamalai peoples have good knowledge about the phytomedicine. The ethano botanical studies revealed that the greens are used to cure sore in the stomach and mouth, prevent the jaundice, fever, cold, cough, Dysentery, Diarrhea, cure the heart diseases, skin diseases, eye diseases, venereal diseases, relief knees pain, body heat and sugar disorder. In addition to this, ethno botanical studies gives some clues to identify some phytochemicals it leads with the support of clinical trials to discover safe medicine for posterity.

Ashok Kumar et al., (2013) suggest, south Indian green leafy vegetables has good sources of food and medicinal health benefits, which can protect from eye problems, iron deficiency and oxidative damage, cancer, diabetes, hepatotoxicity, nephrotoxicity and many microbial attacks. Kumar et al. (2006) indicated that, the food and nutrient consumption of 
adolescent girls' diet did not differ significantly in the categories of families whether they cultivated or did not cultivate leafy vegetable.

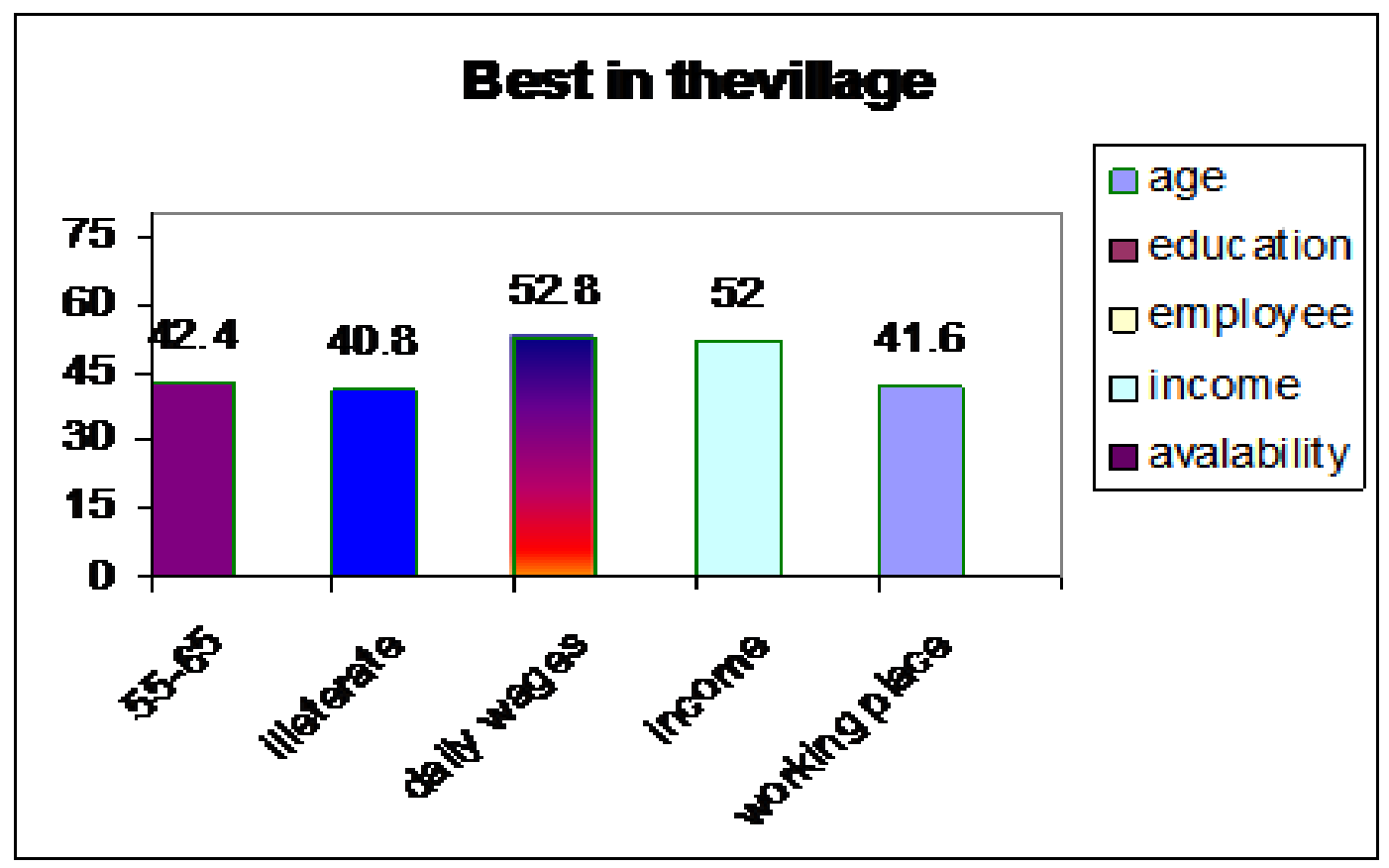

Figure 4. Overall status of the respondent of this study area.

\section{CONCLUSION}

In recent times awareness on the importance of greens is increasing among the educated circle, However in remote villages the illiterates consume variety of greens available at their villages without knowing their scientific review proves that these greens are of immense help to human being by enriching nutrition and curing many diseases as this knowledge is not documented, the younger generation neglects the usage of greens and also their conservation, necessary steps need to be town for creative awareness for the conservation of greens.

\section{Acknowledgement}

The authors are thankful to the Pothamalai tribal peoples for the valuable information they rendered.

\section{References}

[1] B. Arora, S.C. Neha, Swasth Hind 25 (1987) 306-308.

[2] C. K. Ashok Kumar, M. S. Divya Sree Joshna, A. S. Mohana Lakshmi, D. Satheesh Kumar, Journal of Global Trends in Pharmaceutical Sciences 4 (2013) 1248-1256.

[3] R. W. Bussmann, D. Sharon, Journal of Ethnobiology and Ethnomedicine 2 (2006) 47. 
[4] A. Cavender, Journal of Ethnopharmacology 108 (2006) 74-84.

[5] V. S. Kamble, V. D. Jadhav, Int. J. Agricultural \& Food Science 15 (2013) 56-58.

[6] L. M. Kawashima, L. M. V. Soares. Journal of Food Composition and Analysis 16 (2003) 605-611.

[7] R. M. Kunwar, B. K. Nepal, H. B. Kshhetri, S. K. Rai, R.W Bussmann, Journal 124 J. Nat. Hist. Mus. 26 (2006) 2012.

[8] A. R. Kumar, N. Yadav, A. K. Gupta, Parvin, V. Tripathi, V. Verma, The Indian J. Nutr. and Dietetics 43 (2006) 32-38.

[9] P. Leterme, A. Buldgen, F. Estrada, Food Chem 95 (2006) 644-652.

[10] V. M. Nalware, N. S. Reddy, V. N. Kokil, Ind. J. Nutri. Dietet 39 (2001) 81-84.

[11] T. Ogunta, Green leafy vegetables In; Osagie, A. U and Eka, O, U (eds). Nutritional quality of plant foods. Post- harvest research Unit, Department of Biochemistry, University of Benin; Benin City, Nigeria (1998) 120-133.

[12] H. P. Pandey, Economic Botany. Silver Line Publications (2008) 17/3.

[13] A. L.PieroniHoulihan, N. Ansari, B. Husain, S. Astam, Journal of Ethnopharmacology 113 (2007) 100-110.

[14] Praveen Sharma, Gali Vidyasagar, Sunder Singh, Santosh Ghule, Bimlesh Kumar, Journal of Advanced Pharmaceutical Technology and Research 1(1) (2010) 41-48.

[15] G. P. Rao, K. Mallikarjun, G. Gururaja Rao, The Indian J. Nutr. Dietet 17 (1980) 9-12.

[16] C. V. K. Reddy, Nutrition 33(3) (1999) 3-8.

[17] R. Saxena, Nutrition 33(3) (1999) 9-12.

[18] M. S. Teotia, S. K. Berry, S. G. Kulkarni, Sukhuir Kour, J. food sci technol. 25 (1988) 272-275.

[19] S. N. Ughade, S. P. Zodpey, V. A. Khanolkar, Indian Journal of Ophthalmology 46(4) (1988) 221-227. 